\title{
Inhibitory effects of mulberry fruit extract in combination with naringinase on the allergic response in IgE-activated $\mathrm{RBL}-2 \mathrm{H} 3$ cells
}

\author{
JAE-MYUNG YOO ${ }^{1}$, NA YEON KIM ${ }^{1}$, JEONG MIN SEO ${ }^{2}$, SUN-JU KIM ${ }^{2}$, SANG YOON LEE ${ }^{3}$, \\ SANG KYUM KIM ${ }^{3}$, HYUNG DON KIM ${ }^{4}$, SANG WON LEE ${ }^{4}$ and MEE REE KIM ${ }^{1}$ \\ ${ }^{1}$ Department of Food and Nutrition, ${ }^{2}$ Department of Bio-Environmental Chemistry, ${ }^{3}$ College of Pharmacy, \\ Chungnam National University, Yuseong-gu, Daejeon 305-764; ${ }^{4}$ Department of Herbal Crop Research, \\ National Institute of Horticultural and Herbal Science (NIHHS), RDA, Eumseong 369-873, Republic of Korea
}

Received August 19, 2013; Accepted November 21, 2013

DOI: $10.3892 /$ ijmm.2013.1590

\begin{abstract}
In this study, we investigated the anti-allergic action of mulberry fruit extract (MFE) or MFE in combination with naringinase (MFEN) in IgE-activated RBL-2H3 cells, and investigated the mechanisms responsible for the anti-allergic effects of MFEN. $\beta$-hexosaminidase release assay was used to measure the amount of $\beta$-hexosaminidase released from the cells, and ELISA was used to measure the levels of tumor necrosis factor- $\alpha$ (TNF- $\alpha$ ). We found that MFE significantly reduced the release of $\beta$-hexosaminidase $\left(\mathrm{IC}_{50}, 10.59 \mathrm{mg} / \mathrm{ml}\right)$ and TNF- $\alpha\left(\mathrm{IC}_{50}, 4.87 \mathrm{mg} / \mathrm{ml}\right)$. Moreover, MFEN enhanced the inhibitory effects on the release of $\beta$-hexosaminidase $\left(\mathrm{IC}_{50}\right.$, $123.10 \mu \mathrm{g} / \mathrm{ml})$ and TNF- $\alpha\left(\mathrm{IC}_{50}, 65.01 \mu \mathrm{g} / \mathrm{ml}\right)$. Furthermore, MFEN had no cytotoxicity at the concentration range used to exert the anti-allergic effects. In addition, we evaluated the effects of MFEN on the formation of pro-inflammatory lipid mediators, such as prostaglandin $\mathrm{D}_{2}\left(\mathrm{PGD}_{2}\right)$, leukotriene $\mathrm{C}_{4}$ $\left(\mathrm{LTC}_{4}\right)$ and leukotriene $\mathrm{B}_{4}\left(\mathrm{LTB}_{4}\right)$ using enzyme immunoassay (EIA) kits. MFEN markedly reduced the formation of $\mathrm{PGD}_{2}$ $\left(\mathrm{IC}_{50}, 6.47 \mu \mathrm{g} / \mathrm{ml}\right)$ and $\mathrm{LTC}_{4}\left(\mathrm{IC}_{50}, 0.31 \mu \mathrm{g} / \mathrm{ml}\right)$, but not $\mathrm{LTB}_{4}$ $\left(\mathrm{IC}_{50}, 25.75 \mu \mathrm{g} / \mathrm{ml}\right)$. In mechanistic analyses, we measured the phosphorylation of Syk, Lyn and Fyn by immunoblot analysis. MFEN significantly inhibited the phosphorylation of Syk, but not that of Lyn or Fyn. MFEN also suppressed the phosphorylation of phospholipase C (PLC) $\gamma 1 / 2$, protein kinase C (PKC) $\delta$, linker for activation of T cells (LAT), extracellular signalregulated protein kinase (ERK)1/2, JNK, GRB2-associated
\end{abstract}

Correspondence to: Dr Jae-Myung Yoo or Professor Mee Ree Kim, Department of Food and Nutrition, Chungnam National University, 99 Daehak-ro, Yuseong-gu, Daejeon 305-764, Republic of Korea E-mail: jmyoo@cnu.ac.kr

E-mail: mrkim@cnu.ac.kr

Key words: mulberry fruit, naringinase, $\mathrm{RBL}^{2} \mathrm{H} 3$ cells, tumor necrosis factor- $\alpha$, prostaglandin $\mathrm{D}_{2}$, leukotriene $\mathrm{C}_{4}$ binding protein 2 (Gab2), phosphoinositide-3-kinase (PI3K), Akt, cytosolic phospholipase A2 and 5-lipoxygenase, as well as the expression of cyclooxygenase-2. In conclusion, these results suggest that MFEN exerts potent inhibitory effects on allergic response through the suppression of the activation of the FceRI signaling cascade. Our data demonstrating the antiallergic effects of MFEN may provide further insight into the therapeutic application of MFEN or its use as a functional food.

\section{Introduction}

Mulberry fruit (Morus alba L.) has been reported to be have beneficial effects in biological events, such as oxidative stress (1), hyperlipidemia (1), cancer (2), neurodegeneration (3) and inflammation (4). Such effects are associated with polyphenol compounds, such as cyanidin 3-rutinoside, cyanidin 3 -glucoside and rutin in mulberry fruit $(2,4-6)$. Nonetheless, to our knowledge, the inhibitory effects of mulberry fruit on allergic response have not been reported to date.

Naringinase is known as $\alpha$-rhamnopyranoside, possessing the activities of $\alpha$-L-rhamnosidase (E.C. 3.2.1.40) and $\beta$-D-glucosidase (E.C. 3.2.1.21) (7). Thus, the enzyme is able to hydrolyze naringin to release L-rhamnose and naringenin (8). The enzyme has been isolated from plants, yeast, or microorganisms, such as Aspergillus niger (8), Coniothyrium diplodiella (9), Aspergillus terreus (10) and Penicillium decumbens (11). Moreover, the enzyme can also hydrolyze rutin, isoquercetin, hesperidin, diosmin and ter-phenyl glycosides $(7,12)$. Thus, the enzyme has been widely used in biological engineering processes, such as the debittering of fruit juices, preparation of antibiotics, biotransformation of steroids, production of aglycones, production of ginsenosides and the production of glycolipids (7). Nevertheless, to our knowledge, the biological activity of mulberry fruit in combination with naringinase has not been reported to date.

Mast cells play an important role in the initiation and progression of allergy-related diseases, such as asthma, psoriasis and arthritis (13), and cells expressing FceRI receptor on the plasma membrane are also critical cells in the progression of allergic and anaphylactic reactions (14). As the FceRI receptor is known 
to be an immunoglobulin $\mathrm{E}$ ( $\mathrm{IgE}$ ) high-affinity receptor, the activation of the FceRI receptor can promote the liberation of various inflammatory mediators, including histamine, chemotactic factors, cytokines and arachidonate metabolites from IgE-activated mast cells (15). In this respect, RBL-2H3 cells, belonging to mast cell lines (16), have been commonly used for research on IgE-FceRI interactions involving the intracellular signaling cascade and the degranulation and formation of cytokines or eicosanoids (17-19).

Previously, mulberry fruit has been shown to have some beneficial effects in various biological events (1-4), whereas to our knowledge, the inhibitory effects of mulberry fruit on allergic response have not been reported to date. In this respect, we hypothesized that mulberry fruit may exert inhibitory effects on allergic response in IgE-activated mast cells. Thus, in this study, we investigated the anti-allergic action of mulberry fruit extract (MFE) or MFE in combination with naringinase (MFEN) in IgE-activated RBL-2H3 cells, and investigated the mechanisms responsible for the anti-allergic effects of MFEN. The data presented in this study may provide further insight into the therapeutic application of MFEN or its use as a functional food.

\section{Materials and methods}

Reagents. Minimal essential medium (MEM), penicillin, streptomycin and fetal bovine serum (FBS) were purchased from Gibco-Life Technologies (Grand Island, NY, USA). 4-[3-(4-Iodophenyl)-2-(4-nitrophenyl)-2H-5-tetrazolio]-1,3benzene disulfonate (WST-1) was obtained from Dojindo Laboratories (Kumamoto, Japan). Specific antibodies against, Syk, phospho-Syk, Lyn, phospho-Lyn, linker for activation of T cells (LAT), phospho-LAT, extracellular signal-regulated protein kinase 1/2 (ERK1/2), phospho-ERK1/2, JNK, phospho-JNK, GRB2-associated binding protein 2 (Gab2), phospho-Gab2, phosphoinositide-3-kinase (PI3K), phosphoPI3K, Akt, phospho-Akt, phospholipase C (PLC) $\gamma 1$, phospho-PLC $\gamma 1$, PLC $\gamma 2$, phospho-PLC $\gamma 2$, protein kinase $C$ $(\mathrm{PKC}) \delta$, phospho-PKC $\delta$, cytosolic phospholipase $\mathrm{A}_{2}\left(\mathrm{CPLA}_{2}\right)$, phospho-cPLA2, cyclooxygenase-2 (COX-2) and $\beta$-actin were purchased from Cell Signaling Technology, Inc. (Beverly, MA, USA). A specific antibody against phospho-Fyn was obtained from Biorbyt Ltd. (Cambridge, UK). The enzyme-linked immunosorbent assay (ELISA) kit for tumor necrosis factor- $\alpha$ (TNF- $\alpha$ ) was obtained from eBioscience, Inc. (San Diego, CA, USA). Specific antibodies against 5-lipoxygenase (5-LO) and phospho-5-LO, as well as enzyme immunoassay (EIA) kits for prostaglandin $\mathrm{D}_{2}\left(\mathrm{PGD}_{2}\right)$, leukotriene $\mathrm{B}_{4}\left(\mathrm{LTB}_{4}\right)$ and leukotriene $\mathrm{C}_{4}\left(\mathrm{LTC}_{4}\right)$ were purchased from Cayman Chemical, Inc. (Ann Arbor, MI, USA). 4-Nitrophenyl $N$-acetyl- $\beta$-Dglucosaminide (p-NAG), dinitrophenyl (DNP)-IgE, DNPhuman serum albumin (DNP-HSA) and naringinase were obtained from Sigma-Aldrich (St. Louis, MO, USA). All other chemicals were of analytical grade.

Preparation of MFE. Lyophilized mulberry fruit was obtained from S\&D, Inc. (Yeongi, Korea). Lyophilized mulberry fruit $(40 \mathrm{~g})$ was extracted with $80 \%$ ethanol $(1,000 \mathrm{ml})$ in a bath sonicator for 3 days, and the mixture was filtered by Whatman no. 3 filter paper. The total filtrate was lyophilized, and then the residue of MFE (20 g) was completely dissolved in $0.1 \mathrm{M}$ sodium acetate buffer ( $\mathrm{pH} 4.5$ ) containing $2.5 \mathrm{~g}$ naringinase, and then incubated for $18 \mathrm{~h}$ at $40^{\circ} \mathrm{C}(20)$. The solution was added to ethyl acetate $(1: 1 \mathrm{v} / \mathrm{v})$, and then the layer of ethyl acetate was separated and evaporated (evaporator, MG-2100; Buchi, Flawil, Switzerland). The dried residue of ethyl acetate extract $(1 \mathrm{~g})$ was dissolved in ethanol or suspended in water.

Analytical methods. High-performance liquid chromatography (HPLC) analysis was carried out as previously described $(5,6)$. To analyze flavonoids, HPLC analysis was performed using a Perkin-Elmer Flexar (Perkin-Elmer, Inc., Waltham, MA, USA) and a Capcell PAK $\mathrm{C}_{18}$ column $(4.6 \times 250 \mathrm{~mm}, 5 \mu \mathrm{m}$; Shiseido, Tokyo, Japan). The flavonoids were eluted in gradient system composed of solvent A (methanol:water:acetic acid, 5:92.5:2.5; $\mathrm{v} / \mathrm{v} / \mathrm{v}$ ) and solvent B (methanol:water:acetic acid, 95:2.5:2.5; $\mathrm{v} / \mathrm{v} / \mathrm{v})$. The gradient was $10-50-50-60-10-10 \%$ of solvent $\mathrm{B}$ at gradient time ( $t \mathrm{G}, 0-12-17-30-30.1-35 \mathrm{~min}$ ), oven temperature was $40^{\circ} \mathrm{C}$ and the flow rate was $1.0 \mathrm{ml} / \mathrm{min}$; an injection volume of $10 \mu \mathrm{l}$ was applied. Perkin-Elmer Flexar UV/Vis detector was set at a wavelength of 280 and $350 \mathrm{~nm}$. The resulting data and chromatographic profiles were evaluated using the Chromera ${ }^{\circledR}$ Chromatography Data System (Perkin-Elmer, Inc.).

To analyze anthocyanins, HPLC analysis was performed using an Agilent Technologies 1200 series (Agilent Technologies, Wilmington, DE, USA) a Synergi $4 \mu$ Polar-RP $80 \mathrm{~A}(250 \times 4.6 \mathrm{~mm}, 4 \mu \mathrm{m})$ and a guard column $\left(\mathrm{AQC}_{18} 4 \times 3.0 \mathrm{~mm}\right)$ (both from Phenomenex, Inc., Torrance, CA, USA). The anthocyanins were eluted in gradient system composed of solvent $\mathrm{A}$ (water:formic acid, 95:5; v/v) and solvent B (acetonitrile:formic acid, $95: 5 ; v / v)$. The gradient was $0-10-13-15-15-5-5 \%$ of solvent $\mathrm{B}$ at gradient time ( $t \mathrm{G}=0-8-15-18-25-25.1-35 \mathrm{~min})$, oven temperature was $40^{\circ} \mathrm{C}$ and the flow rate was $1.0 \mathrm{ml} / \mathrm{min}$; an injection volume of $10 \mu \mathrm{l}$ was applied. The UV/Vis detector was set at a wavelength of $520 \mathrm{~nm}$. The resulting data and chromatographic profiles were evaluated using Analyst software (version 1.4.2; Applied Biosystems, Foster City, CA, USA). Separately, to identify flavonoid compounds using the liquid chromatography-electrospray tandem mass spectrometry (LC-ESI/MS/MS), LC-ESI/MS/MS analysis was evaluated following a previously described method (21). The LC-ESI/ MS/MS system consisted of an Shimadzu 20AD-XR HPLC system (Shimadzu, Kyoto, Japan) and an API 3200 Q-TRAP LC-MS/MS system equipped with a Turbo V Ion Spray ${ }^{\mathrm{TM}}$ source (Applied Biosystems) operated in the negative ion mode. The sample injection volume was $10 \mu \mathrm{l}$ and the separation was performed on a XTerra ${ }^{\mathrm{TM}} 3.5 \mu \mathrm{C}_{18}$ column $(2.1 \times 50 \mathrm{~mm}$ i.d.; Waters, Milford, MA, USA) with a SecurityGuard ${ }^{\mathrm{TM}} \mathrm{C}_{18}$ guard column (2.0x4.0 mm i.d.; Phenomenex, Inc.). The samples were analyzed via multiple reaction monitoring (MRM). Quantification was performed by MRM of the [M-H] $]^{-}$ion and the related production for quercetin, using an internal standard to establish peak area ratios.

Acquisition and data analysis were performed using Analyst $^{\mathrm{TM}}$ software (version 1.5.2; Applied Biosystems). Calibration standards (3.9-1,000 $\mathrm{nM})$ were prepared in blank matrices pre-treated with ice-cold acetonitrile containing 4-methylumbelliferone (internal standard); the pre-treatment of blank matrices was necessary due to the instability of the analytes in the matrices. Calibration curves constructed using 
linear least-squares regression were linear over the concentration range of the standards used $\left(r^{2}>0.999\right)$. Relative standard deviation (RSD) of the measured concentrations was used to assess the precision. A comparison of the mean measured concentration versus the corresponding nominal concentration was used to assess the accuracy. Both the accuracy (80-120\%) and precision $(\mathrm{RSD}<20 \%)$ of the assay were acceptable.

Cell culture. RBL-2H3 cells were cultured in MEM containing $5 \%$ (v/v) FBS, $100 \mathrm{U} / \mathrm{ml}$ penicillin and $100 \mu \mathrm{g} / \mathrm{ml}$ streptomycin at $37^{\circ} \mathrm{C}$ in a humidified atmosphere of $5 \% \mathrm{CO}_{2}$ as previously described (22).

Cytotoxicity assay. Cell respiration, an indicator of cell viability, was determined by measuring the mitochondrialdependent reduction of WST-1 to water-soluble tetrazolium salt, as previously described (23). Briefly, the RBL-2H3 cells were seeded on a 96 -well plate $\left(1 \times 10^{4}\right.$ cells/well $)$ in MEM with $5 \% \mathrm{FBS}$ at $37^{\circ} \mathrm{C}$ overnight. The cells were washed, and then incubated with DNP-IgE $(1 \mu \mathrm{g} / \mathrm{ml})$ for $24 \mathrm{~h}$. The IgE-sensitized cells were incubated with MFEN at various concentrations (0-200 $\mu \mathrm{g} / \mathrm{ml})$ for $1 \mathrm{~h}$. Both DNP-HSA (25 $\mathrm{ng} / \mathrm{ml})$ and WST-1 reagent $(10 \mu \mathrm{l})$ were simultaneously added to the above, and the mixture was incubated for a further $4 \mathrm{~h}$. To measure cell viability, the absorbance was measured at $450 \mathrm{~nm}$ using a microplate reader (Emax; Molecular Devices Inc., Sunnyvale, CA, USA).

$\beta$-hexosaminidase release activity. The $\mathrm{RBL}-2 \mathrm{H} 3$ cells were incubated in a 24 -well plate $\left(1 \times 10^{5}\right.$ cells/well $)$ at $37^{\circ} \mathrm{C}$ overnight. The above cells were washed with $1 \mathrm{X}$ PBS, and then incubated with DNP-IgE for $24 \mathrm{~h}$. IgE-sensitized cells were incubated with MFEN (0-200 $\mu \mathrm{g} / \mathrm{ml})$ for $1 \mathrm{~h}$, spiked with DNP-HSA, and then incubated for a further $4 \mathrm{~h}$. To measure the amount of $\beta$-hexosaminidase activity released from the cells, the culture medium was transferred and centrifuged $(17,000 \mathrm{x} \mathrm{g}$ for $10 \mathrm{~min})$ at $4^{\circ} \mathrm{C}$. The supernatant $(25 \mu \mathrm{l})$ was mixed with $50 \mu \mathrm{l}$ p-NAG $(10 \mathrm{mM})$ in $0.1 \mathrm{M}$ sodium citrate buffer $(\mathrm{pH} 4.5)$ into a 96-well plate, and then incubated for $1 \mathrm{~h}$ at $37^{\circ} \mathrm{C}$. The reaction was terminated by stop buffer $\left(0.1 \mathrm{M} \mathrm{Na}_{2} \mathrm{CO}_{3}\right.$ buffer, $\left.\mathrm{pH} 10.0\right)$. The $\beta$-hexosaminidase activity was determined by measuring the difference in absorbance at $405 \mathrm{~nm}$.

ELISA of TNF- $\alpha$. To measure the TNF- $\alpha$ level in the culture medium, all culture media were centrifuged $(17,000 \mathrm{x} \mathrm{g}$ for $10 \mathrm{~min}$ ) at $4^{\circ} \mathrm{C}$, and the samples were stored at $-80^{\circ} \mathrm{C}$ until use. The concentration of TNF- $\alpha$ was determined using ELISA kits (eBioscience, Inc.) according to the manufacturer's instructions.

EIA of $\mathrm{PGD}_{2}, \mathrm{LTB}_{4}$ and $\mathrm{LTC}_{4}$. To determine the levels of $\mathrm{PGD}_{2}$, $\mathrm{LTB}_{4}$ and $\mathrm{LTC}_{4}$ in the culture medium, all culture media were centrifuged $(17,000 \mathrm{x} \mathrm{g}$ for $10 \mathrm{~min})$ at $4^{\circ} \mathrm{C}$, and the supernatant was stored at $-80^{\circ} \mathrm{C}$ until use. The concentrations of $\mathrm{PGD}_{2}$, $\mathrm{LTB}_{4}$ and $\mathrm{LTC}_{4}$ were determined using EIA kits (Cayman Chemical, Inc.) according to the manufacturer's instructions.

Immunoblot analysis. Immunoblot analysis was carried out according toa previously described method(24). The membranes were then incubated with a 1:1,000 dilution of specific antibodies against phospho-PLC $\gamma 1$, PLC $\gamma 1$, phospho-PLC $\gamma 2$,

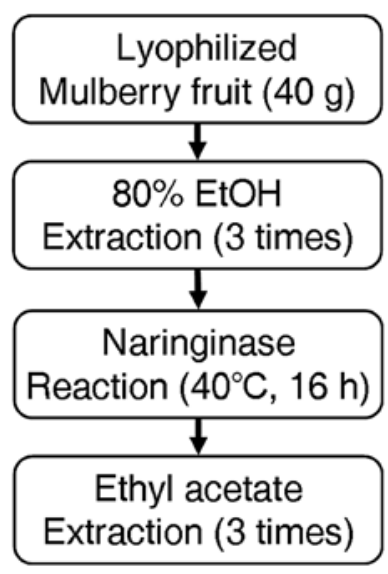

Figure 1. Schematic diagram of the procedure for obtaining the mulberry fruit extracts in combination with naringinase.

PLC $\gamma 2$, phospho-PKC $\delta$, PKC $\delta$, phospho-Fyn, phospho-Lyn, Lyn, phospho-Syk, Syk, phospho-LAT, LAT, phospho-ERK1/2, ERK1/2, phospho-JNK, JNK, phospho-Gab2, phospho-PI3K, PI3K, phospho-Akt, Akt, phospho-cPLA 2 , cPLA 2 , COX-2 and $\beta$-actin (Cell Signaling Technology, Inc.), and antibodies against phospho-5-LO and 5-LO (Cayman Chemical, Inc.). The blots were washed with TBS-T, and then incubated with a 1:5,000 dilution of horseradish peroxidase-conjugated IgG secondary antibody (Cell Signaling Technology, Inc.). The proteins on the membranes were detected using a chemiluminescent reaction (ECL plus kit), followed by the exposure of the membranes to Hyperfilm ECL (both from Amersham Pharmacia Biotech, Buckinghamshire, UK). The levels of the target proteins were compared to those of a loading control ( $\beta$-actin or non-phosphorylated protein), and then the density of the resolved bands was evaluated using ImageJ software.

Statistical analysis. The experimental results are expressed as the means \pm SD. One-way analysis of variance (ANOVA) was used for multiple comparisons (GraphPad Prism version 4.03 for Windows; GraphPad Software, San Diego, CA, USA). If there was a significant variation between the treatment groups, the Dunnett test was applied. Values of $\mathrm{P}<0.05$ and $\mathrm{P}<0.01$ were considered to indicate statistically significant differences.

\section{Results}

Inhibitory effects of MFE or MFEN on IgE-mediated allergic response in $\mathrm{RBL}-2 \mathrm{H} 3$ cells. First, to determine the effects of MFE on IgE-antigen complex reaction, the IgE-sensitized RBL-2H3 cells were exposed to MFE at various concentrations $(0-75 \mathrm{mg} / \mathrm{ml})$ for $1 \mathrm{~h}$, and then stimulated with $25 \mathrm{ng} / \mathrm{ml}$ of DNP-HSA for $4 \mathrm{~h}$. MFE markedly inhibited the release of both $\beta$-hexosaminidase ( $\mathrm{IC}_{50}, 10.59 \mathrm{mg} / \mathrm{ml}$ ), a general biomarker of degranulation, and TNF- $\alpha\left(\mathrm{IC}_{50}, 4.87 \mathrm{mg} / \mathrm{ml}\right)$, a pro-inflammatory cytokine (Fig. 2). When the IgE-sensitized RBL-2H3 cells were exposed to MFEN, MFE in combination with naringinase (Fig. 1) at various concentrations $(0-200 \mu \mathrm{g} / \mathrm{ml})$ for $1 \mathrm{~h}$ prior to antigen challenge, (Fig. 3A and B), MFEN markedly suppressed the release of both $\beta$-hexosaminidase $\left(\mathrm{IC}_{50}, 123.10 \mu \mathrm{g} / \mathrm{ml}\right)$ and TNF- $\alpha\left(\mathrm{IC}_{50}, 65.01 \mu \mathrm{g} / \mathrm{ml}\right)$. Moreover, 

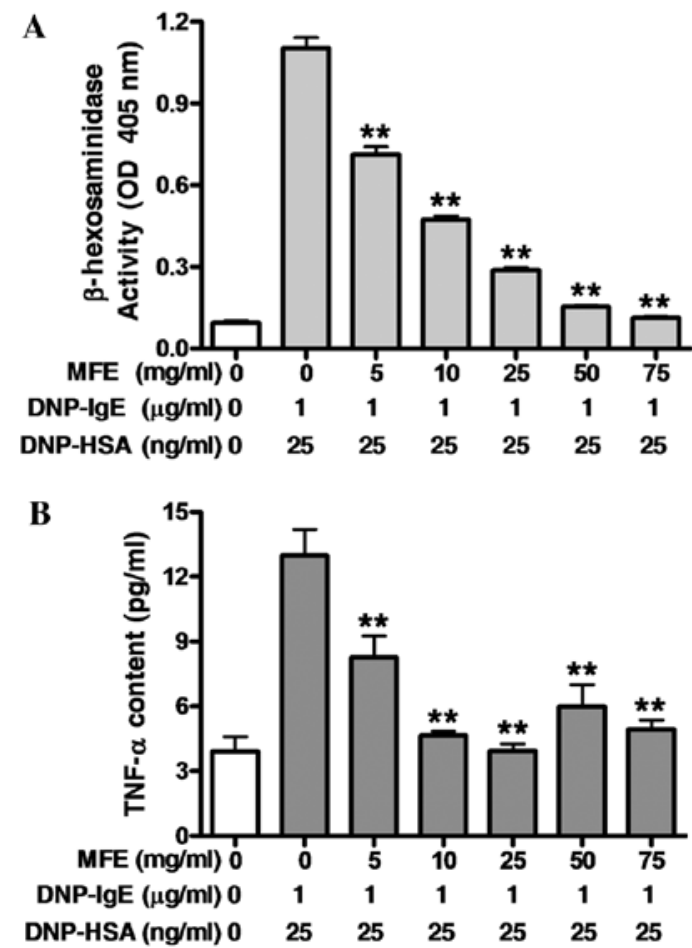

Figure 2. Inhibitory effects of mulberry fruit extract (MFE) on the release of (A) $\beta$-hexosaminidase or (B) tumor necrosis factor- $\alpha$ (TNF- $\alpha$ ) from IgE-activated RBL-2H3 cells. RBL-2H3 cells were seeded on a 24-well plate $\left(1 \times 10^{5}\right.$ cells/well) in MEM with $5 \%$ fetal bovine serum (FBS) at $37^{\circ} \mathrm{C}$ overnight, and further incubated with dinitrophenyl-immunoglobulin $\mathrm{E}$ (DNP-IgE) for $24 \mathrm{~h}$. IgE-sensitized cells were exposed to MFE $(0-75 \mathrm{mg} / \mathrm{ml})$ for $1 \mathrm{~h}$, and then stimulated with DNP-human serum albumin (DNP-HSA) $(25 \mathrm{ng} / \mathrm{ml})$ for $4 \mathrm{~h}$. $\beta$-hexosaminidase activity and the TNF- $\alpha$ level were determined as described in Materials and methods. Data are the means \pm SD values of triple determinations. ${ }^{* *} \mathrm{P}<0.01$ vs. DNP-HSA-treated group.

MFEN had no significant cytotoxicity at the concentrations used to inhibit degranulation (Fig. 3C). Taken together, these results indicate that MFE possesses anti-allergic activity, and that the anti-allergic activity of MFE may be derived from certain bioactive components, such as cyanidin 3-rutinoside, cyanidin 3-glucoside or rutin. In addition, treatment with naringinase enhanced the inhibitory effects on allergic response in IgE-activated mast cells. These effects of MFEN may be associated with aglycones, which are released from glycosides.

Inhibitory effects of MFEN on the formation of pro-inflammatory lipid mediators. We then examined the effects of MFEN on the formation of pro-inflammatory lipid mediators, such as $\mathrm{PGD}_{2}, \mathrm{LTB}_{4}$ and $\mathrm{LTC}_{4}$ associated with allergic response $(16,25-28)$, since the activation of the arachidonate cascade is involved in FceRI activation in IgE-activated mast cells (29). RBL-2H3 cells were pre-incubated with MFEN $(0-200 \mu \mathrm{g} / \mathrm{ml})$ prior to antigen challenge, and the formation of $\mathrm{PGD}_{2}, \mathrm{LTB}_{4}$ or $\mathrm{LTC}_{4}$ was then assessed. MFEN markedly inhibited the formation of both $\mathrm{PGD}_{2}\left(\mathrm{IC}_{50}, 6.47 \mu \mathrm{g} / \mathrm{ml}\right)$ and $\mathrm{LTC}_{4}\left(\mathrm{IC}_{50}, 0.31 \mu \mathrm{g} / \mathrm{ml}\right)$, whereas it only slightly suppressed the formation of $\mathrm{LTB}_{4}\left(\mathrm{IC}_{50}, 25.75 \mu \mathrm{g} / \mathrm{ml}\right)$ (Fig. 4). Taken together, these results suggest that MFEN suppresses allergic inflammation induced by $\mathrm{PGD}_{2}, \mathrm{LTC}_{4}$ or $\mathrm{LTB}_{4}$. Thus, this indicates that MFEN directly inhibits an enzyme involved in the biosynthesis of prostaglandins or leukotrienes. In particular, our results indi-
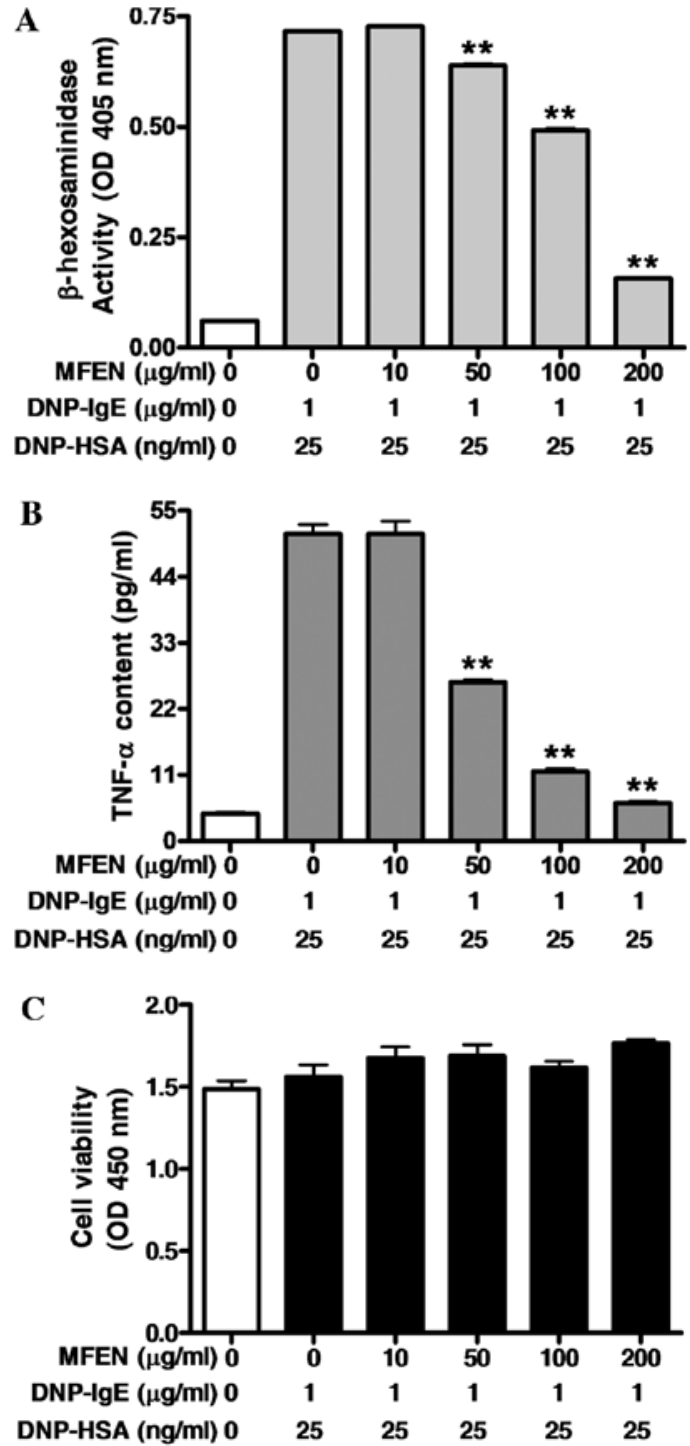

Figure 3. Effects of mulberry fruit extract in combination with naringinase (MFEN) on the release of (A) $\beta$-hexosaminidase or (B) tumor necrosis factor- $\alpha(\mathrm{TNF}-\alpha)$, and $(\mathrm{C})$ on the cell viability in immunoglobulin $\mathrm{E}(\operatorname{IgE})$ activated RBL-2H3 cells. The release of $\beta$-hexosaminidase activity or TNF- $\alpha$ was determined as described in Fig. 2. Separately, IgE-sensitized cells were exposed to MFEN (0-200 $\mu \mathrm{g} / \mathrm{ml})$ for $1 \mathrm{~h}$, and then simultaneously treated with dinitrophenyl-human serum albumin (DNP-HSA) $(25 \mathrm{ng} / \mathrm{ml})$ and WST-1 reagent $(10 \mu \mathrm{l})$ for $4 \mathrm{~h}$. Cell viability was determined as described in Materials and methods. Data are the means \pm SD values of octuple determinations. ${ }^{* *} \mathrm{P}<0.01$ vs. DNP-HSA-treated group.

cate that MFEN potently inhibits the formation of $\mathrm{LTC}_{4}$, and MFEN may contain a specific inhibitor against $\mathrm{LTC}_{4}$ synthase.

Regulatory effects of MFEN on the FcERI signaling pathway. We then investigated the mechanisms responsible for the antiallergic effects of MFEN. The activation of the FceRI receptor is known to be associated with the phosphorylation of Lyn and Syk, which mediate the induction of degranulation in mast cells (27). Quercetin, an aglycone of isoquercetin or rutin, is known to inhibit the degranulation of IgE-activated RBL-2H3 cells (30). Thus, we hypothesized that MFEN can affect the phosphorylation of Lyn or Syk, as well as the FceRI cascade. When the IgE-sensitized RBL-2H3 cells were pre-incubated 
Table I. Composition of anthocyanins and flavonoids of MFE or MFEN.

\begin{tabular}{lccccccc}
\hline & \multicolumn{3}{c}{ Anthocyanins } & & \multicolumn{3}{c}{ Flavonoids } \\
\cline { 2 - 3 } & C3G & C3R & Cyanidin & & Isoquercetin & Rutin & Quercetin \\
\hline MFE & $6.16 \pm 0.08$ & $4.11 \pm 0.04$ & $0.04 \pm 0.00$ & & $3.67 \pm 0.03$ & $3.67 \pm 0.03$ & ND \\
MFEN & $0.12 \pm 0.01$ & ND & ND & & ND & ND & $19.60 \pm 6.35$
\end{tabular}

Data are the means \pm SD values of triple determinations. C3G, cyanidin 3-glucoside; C3R, cyanidin 3-rutinoside; ND, not detected; MFE, mulberry fruit extract; MFEN, MFE in combination with naringinase. Values are expressed in $\mathrm{mg} / \mathrm{g}$ dry weight.
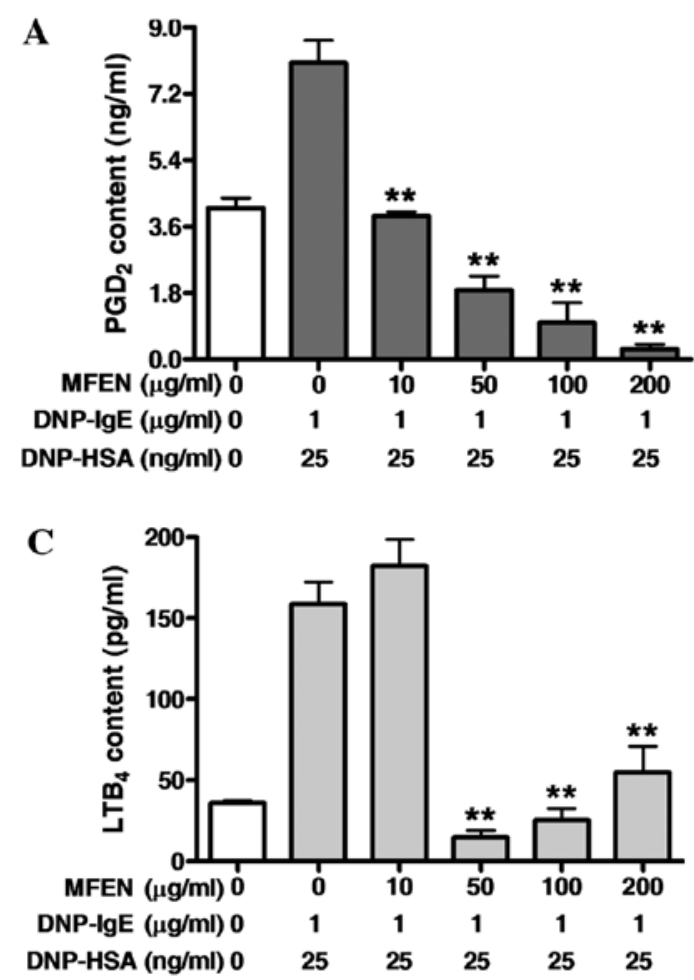

with MFEN (0-200 $\mu \mathrm{g} / \mathrm{ml})$ for $1 \mathrm{~h}$ prior to antigen challenge, and then the incubation was extended for a further $10 \mathrm{~min}$, MFEN markedly inhibited Syk phosphorylation, but not that of Lyn or Fyn (Fig. 5A). MFEN dose-dependently suppressed the activation of PLC $\gamma 1 / 2$ and PKC $\delta$, implicated in the degranulation process in mast cells (28) (Fig. 5B). Additionally, MFEN reduced the phosphorylation of Gab2, PI3K, Akt, LAT, ERK1/2 and JNK (Fig. 5C and D). These findings indicate that MFEN may directly block the activation of Syk. Consequently, MFEN also inhibited the activation of other targets, such as PLC $\gamma 1 / 2$, PKC8, Gab2, PI3K, Akt, LAT, ERK1/2 and JNK on the FceRI cascade in IgE-activated mast cells.

Regulatory effects of MFEN on the enzymes associated with the arachidonate cascade. We additionally investigated the anti-allergic effects of MFEN on the activation of enzymes associated with the arachidonate cascade. The activation of the arachidonate cascade has been implicated in the activation of the FceRI receptor in IgE-activated mast cells (27). In this respect, we hypothesized that MFEN, which showed antiallergic effects, would affect the activation of $\mathrm{cPLA}_{2}, 5-\mathrm{LO}$ or

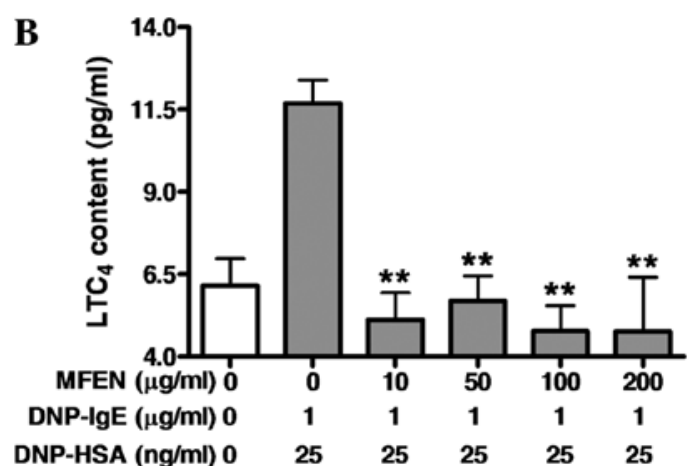

Figure 4. Inhibitory effects of mulberry fruit extract in combination with naringinase (MFEN) on the formation of (A) prostaglandin $\mathrm{D}_{2}\left(\mathrm{PGD}_{2}\right)$, (B) leukotriene $\mathrm{C}_{4}\left(\mathrm{LTC}_{4}\right)$, and $(\mathrm{C})$ leukotriene $\mathrm{B}_{4}\left(\mathrm{LTB}_{4}\right)$ in immunoglobulin E (IgE)-activated RBL-2H3 cells. IgE-sensitized RBL-2H3 cells were exposed to MFEN $(0-200 \mu \mathrm{g} / \mathrm{ml})$ for $1 \mathrm{~h}$, and then stimulated with dinitrophenyl-human serum albumin (DNP-HSA) $(25 \mathrm{ng} / \mathrm{ml})$ for $4 \mathrm{~h}$. The amount of $\mathrm{PGD}_{2}, \mathrm{LTC}_{4}$ or $\mathrm{LTB}_{4}$ was determined as described in Materials and methods. Data are the means \pm SD values of octuple determinations. ${ }^{* *} \mathrm{P}<0.01$ vs. DNP-HSA-treated group.

COX-2. When the IgE-sensitized RBL-2H3 cells were exposed to MFEN at various concentrations for $1 \mathrm{~h}$ prior to stimulation with the antigen, and then the incubation was extended for a further $4 \mathrm{~h}$, MFEN suppressed the phosphorylation of $\mathrm{CPLA}_{2}$ and 5-LO, as well as the expression of COX-2 (Fig. 6). These findings indicate that MFEN suppresses the activation of $\mathrm{cPLA}_{2}, 5-\mathrm{LO}$ and COX-2. In particular, since MFEN at $50 \mu \mathrm{g} /$ $\mathrm{ml}$ strongly inhibited the activation of 5-LO, the composition of MFEN may include a specific inhibitor against 5-LO.

Inhibitory effects of quercetin on IgE-mediated allergic response and flavonoid profiles of MFEN. Finally, to substantiate that MFEN includes quercetin, we analyzed the chemical profiles for anthocyanins and quercetin or its glycosides, such as isoquercetin and rutin using HPLC and LC-ESI/MS/MS. MFE contained cyanidin 3-glucoside, cyanidin 3-rutinoside, isoquercetin and rutin, but not quercetin (Table I). On the other hand, MFEN showed an increase in the amount of quercetin, and all the amounts of glycoside compounds, including isoquercetin and rutin were reduced by treatment with naringinase. In addition, to confirm the anti-allergic effects of 

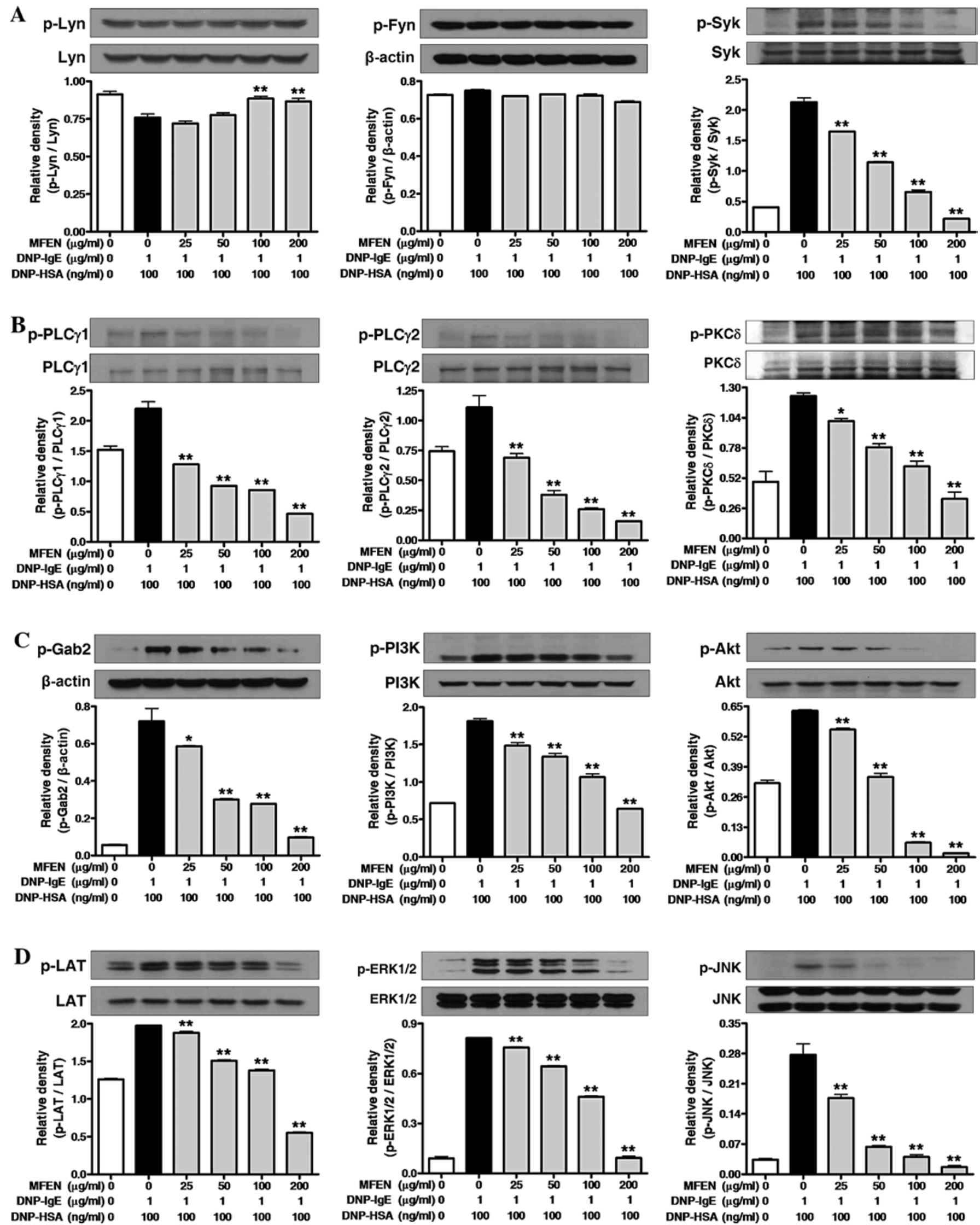

Figure 5. Effects of mulberry fruit extract in combination with naringinase (MFEN) on the early stage of the FceRI signaling cascade in immunoglobulin E (IgE)-activated RBL-2H3 cells. IgE-sensitized RBL-2H3 cells were exposed to MFEN $(0-200 \mu \mathrm{g} / \mathrm{ml})$ for $1 \mathrm{~h}$, and then stimulated by dinitrophenyl-human serum albumin (DNP-HSA) $(100 \mathrm{ng} / \mathrm{ml}$ ) for $10 \mathrm{~min}$. The cells were rinsed with 1X PBS, and lysed with cell lysis buffer. The expression of (A) phoshoprylated (p-)Lyn, Lyn, p-Fyn, p-Syk, Syk, (B) p-PLC $\gamma 1$, PLC $\gamma 1$, p-PLC $\gamma 2$, PLC $\gamma 2$, p-PKCס, PKC8, (C) p-Gab2, p-PI3K, PI3K, p-Akt, Akt, (D) p-LAT, LAT, p-ERK1/2, ERK1/2, $\mathrm{p}$-JNK, JNK or $\beta$-actin was determined as described in Materials and methods. Similar results were obtained in 3 independent experiments. ${ }^{*} \mathrm{P}<0.05$ and ${ }^{* *} \mathrm{P}<0.01$ vs. DNP-HSA-treated group. 
A
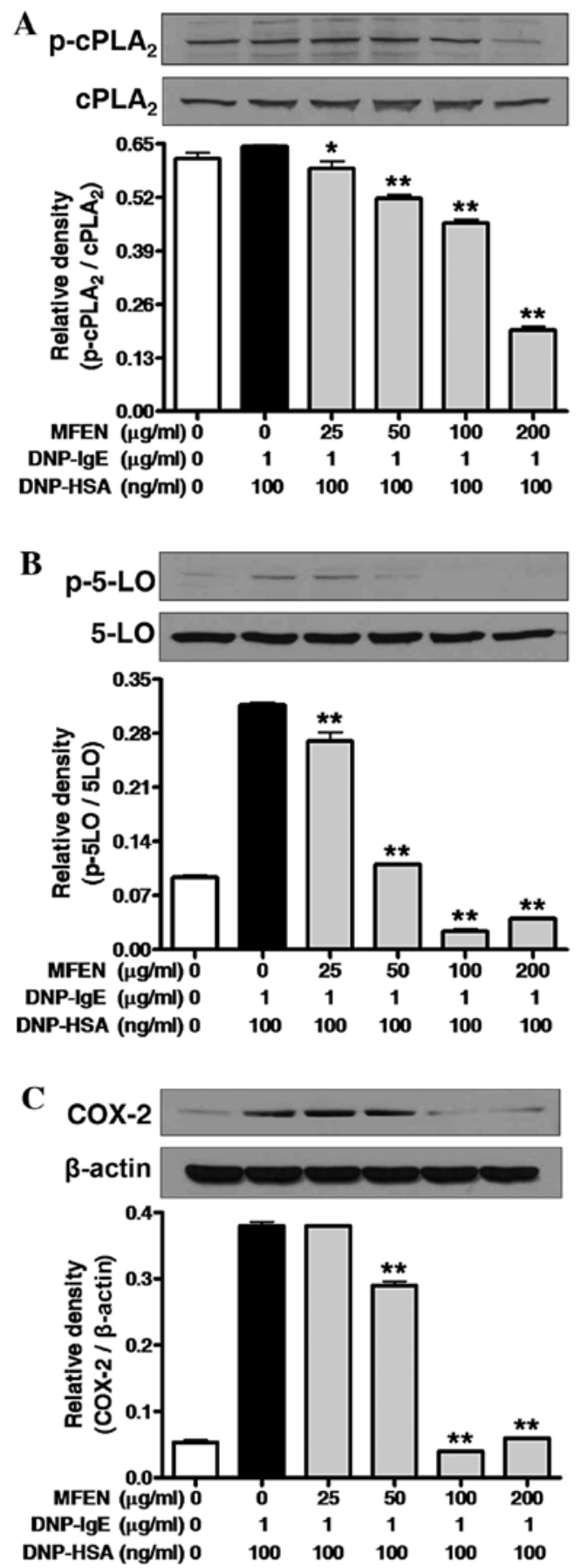

Figure 6. Effects of mulberry fruit extract in combination with naringinase (MFEN) on the late stage of the FceRI cascade in immunoglobulin E (IgE)activated RBL-2H3 cells. IgE-sensitized RBL-2H3 cells were exposed to MFEN $(0-200 \mu \mathrm{g} / \mathrm{ml})$ for $1 \mathrm{~h}$, and then stimulated by dinitrophenyl-human serum albumin (DNP-HSA) $(100 \mathrm{ng} / \mathrm{ml})$ for $4 \mathrm{~h}$. The cells were rinsed with 1X PBS, and lysed with cell lysis buffer. The expression of (A) phosphorylated (p-)cytosolic phospholipase $\mathrm{A}_{2}$ ( $\mathrm{cPLA}_{2}$ ), cPLA $\mathrm{CP}_{2}$, (B) p-5-lipoxygenase (5-LO), 5 -LO, (C) cyclooxygenase-2 (COX-2) or $\beta$-actin was determined as described in Materials and methods. Similar results were obtained in 3 independent experiments. ${ }^{*} \mathrm{P}<0.05$ and ${ }^{* *} \mathrm{P}<0.01$ vs. DNP-HSA-treated group.

quercetin, found in high quantities in MFEN, we examined the IgE-sensitized RBL-2H3 cells exposed to quercetin at various concentrations $(0-80 \mu \mathrm{M})$ for $1 \mathrm{~h}$, and then stimulated with $25 \mathrm{ng} / \mathrm{ml}$ of DNP-HSA for $4 \mathrm{~h}$. Quercetin markedly inhibited the release of both $\beta$-hexosaminidase $\left(\mathrm{IC}_{50}, 17.58 \mu \mathrm{M}\right)$ and
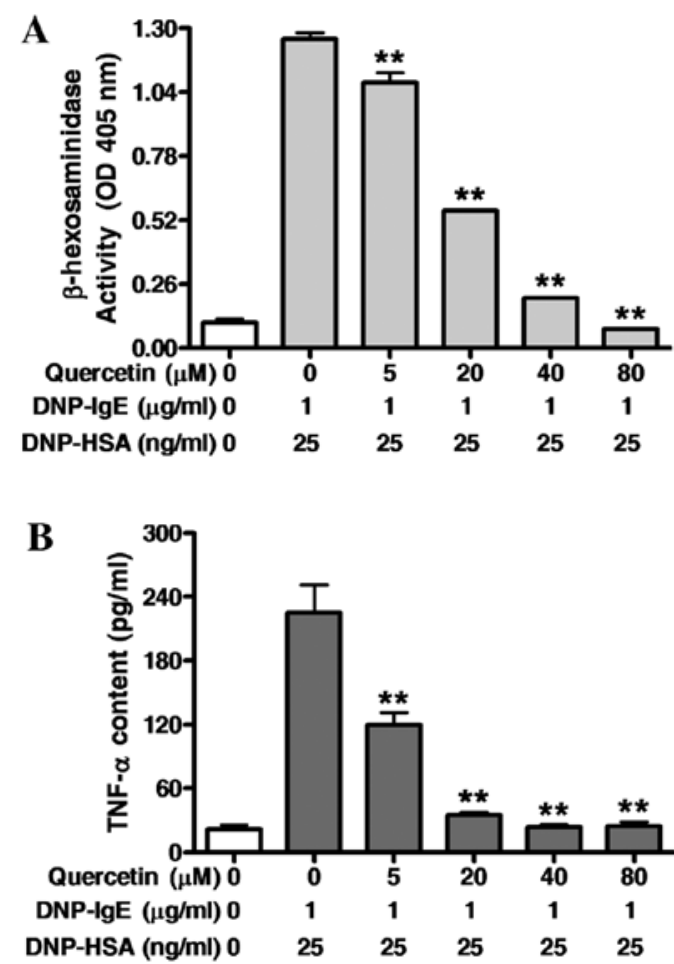

Figure 7. Inhibitory effects of quercetin on the release of (A) $\beta$-hexosaminidase or (B) tumor necrosis factor- $\alpha$ (TNF- $\alpha$ ) from immunoglobulin $\mathrm{E}$ (IgE)activated RBL-2H3 cells. The release of $\beta$-hexosaminidase activity or TNF- $\alpha$ was determined as described in Fig. 2. Data are the means \pm SD values of octuple determinations. ${ }^{* *} \mathrm{P}<0.01$ vs. dinitrophenyl-human serum albumin (DNP-HSA)-treated group.

TNF- $\alpha\left(\mathrm{IC}_{50}, 4.80 \mu \mathrm{M}\right)$ (Fig. 7). Taken together, these results indicate that MFEN contains a high level of quercetin, whereas the glycoside compounds in MFEN are reduced by naringinase. Consequently, the anti-allergic effects of MFEN may be derived from quercetin.

\section{Discussion}

Previously, mulberry fruit has been reported to possess some biological properties, such as antioxidant (1), antihyperlipidemic (1), anti-cancer (2), anti-neurodegenerative (3) and anti-inflammatory properties (4). Mulberry fruit is also known to be rich in polyphenolic compounds, such as cyanidin 3-rutinoside, cyanidin 3-glucoside and rutin, associated with such beneficial effects $(2,4-6)$. Nevertheless, to our knowledge, the inhibitory effects of mulberry fruit on allergic response have not been reported to date.

Separately, naringinase is known to possess the activities of $\alpha$-L-rhamnosidase (EC 3.2.1.40) and $\beta$-D-glucosidase (EC 3.2.1.21) (7). Thus, the enzyme can also hydrolyze cyanidin 3-glucoside, cyanidin 3-rutinoside, isoquercetin or rutin, which found in rich quantities in mulberry fruit, to aglycones with glucose or rutinose $(7,12)$. In support of this, MFE contains cyanidin 3-glucoside, cyanidin 3-rutinoside, isoquercetin and rutin, but not quercetin. In our study, when MFE was incubated with naringinase, the amount of quercetin in MFEN was highly elevated, whereas the amount of isoquercetin or rutin was not detected. Moreover, the anti-allergic effects of MFEN 
were more potent than those of MFE. In this respect, cyanidin or quercetin, released from cyanidin 3-glucoside or cyanidin 3 -rutinoside, isoquercetin or rutin, respectively, may be core chemicals with anti-allergic properties. Although mulberry fruit has been known to contain richer quantities of cyanidin 3 -glucoside or cyanidin 3-rutinoside than isoquercetin or rutin (5), cyanidin or cyanidin 3-glucoside have been known to poorly inhibit allergic response in IgE-activated mast cells (31). In addition, in our study, cyanidin 3-glucoside did not inhibit degranulation and TNF- $\alpha$ release in IgE-activated RBL-2H3 cells (data not shown). Quercetin is known to exert a more potent inhibitory effect than cyanidin on allergic response in IgE-activated mast cells (30). In support of this, in our study, MFEN and quercetin inhibited degranulation and TNF- $\alpha$ release in IgE-activated RBL-2H3 cells. Furthermore, the combination of naringinase and mulberry fruit enhanced the anti-allergic activity. This may also enhance other beneficial effects, and such effects may be derived from quercetin.

Concerning the mechanism responsible for the anti-allergic activity of MFEN, one possible mechanism may involve the direct inhibition of the FceRI cascade. The IgE-induced degranulation in mast cells is related to the activation of the FceRI receptor, and this activation induces the release of various inflammatory mediators containing TNF- $\alpha$, leukotrienes and prostaglandins through the phosphorylation of the Lyn or Fyn/Syk pathway $(28,32)$. Consequently, the activation of Syk leads to the increase in intracellular $\mathrm{Ca}^{2+}$ levels and the activation of the MAP kinase family (28). Thus, Lyn, Fyn and Syk are important intracellular mediators in the early signaling pathway of FceRI receptor activation. In the present study, the inhibition of Syk by MFEN may support the notion that a primary target of MFEN may be Syk. In support of this, MFEN significantly reduced the phosphorylation of Gab2, PI3K, Akt, LAT, ERK1/2 and JNK, which belongs to a downstream protein in the FceRI receptor cascade (28). In addition, MFEN suppressed the activation of PLC $\gamma 1 / 2$ and $\mathrm{PKC} \delta$, which are involved in the process of IgE-mediated degranulation in mast cells (33).

Although MFEN did not completely suppress both cPLA phosphorylation and COX-2 expression, it markedly reduced the levels of $\mathrm{PGD}_{2}$, corresponding to the $\mathrm{COX}-2$ product. Thus, these findings suggest that MFEN directly inhibits COX-2 activity or $\mathrm{PGD}_{2}$ synthase in prostaglandin biosynthesis. MFEN at $50 \mu \mathrm{g} / \mathrm{ml}$ completely inhibited the phosphorylation of 5-LO, whereas MFEN had more potent inhibitory effects on the formation of $\mathrm{LTB}_{4}$ and $\mathrm{LTC}_{4}$, corresponding to the 5-LO product, than 5-LO activation. Thus, these findings suggest that MFEN directly inhibits 5-LO activation, as well as $\mathrm{LTB}_{4}$ hydrolase or $\mathrm{LTC}_{4}$ synthase. Therefore, the inhibitory effects of MFEN on the formation of $\mathrm{PGD}_{2}, \mathrm{LTB}_{4}$ and $\mathrm{LTC}_{4}$ may be involved in its anti-allergic action. $\mathrm{PGD}_{2}$ is known to cause bronchoconstriction, vasodilation, increase capillary permeability and mucous production in asthma (25). $\mathrm{LTB}_{4}$ is a potent chemoattractant and activator of neutrophils and other immune cells in severe asthma $(34,35) ; \mathrm{LTC}_{4}$ is known to be a potent spasmogenic and chemotactic biochemical and an agonist of cysteinyl-LT receptors, which is known to induce chronic inflammatory reactions in allergic diseases (26). Taken together, our results suggested that MFEN inhibited allergic reaction through the suppression of Syk, PLC $\gamma 1 / 2, \operatorname{PKC} \delta$,
Gab2, PI3K, Akt, LAT, ERK1/2 and JNK, as well as the activation of $\mathrm{CPLA}_{2}, 5-\mathrm{LO}$ and COX-2. Furthermore, such an effect of MFEN may be extended to its anti-inflammatory effects on other cells or tissues. Several cytokines may play critical roles in allergic inflammation (13). In particular, TNF- $\alpha$, secreted from mast cells in IgE-antigen complex reaction (36), is known to play an important role in allergic reaction (13). Moreover, the expression of TNF- $\alpha$ is related to the JNK or ERK1/2 activation of the FceRI cascade in IgE-activated mast cells $(28,33)$. In the present study, MFEN markedly inhibited the activation ERK1/2 and JNK, and reduced the TNF- $\alpha$ level. Therefore, the reduction of TNF- $\alpha$ formation by MFEN may provide an additional advantage of MFEN as an anti-allergic food.

In conclusion, the present study demonstrates that MFEN possesses anti-allergic functions in IgE-activated RBL-2H3 cells. These findings reveal a novel feature of MFEN in allergic response. The mechanisms responsible for its anti-allergic effects may involve multiple targets, including Syk, PLC $\gamma 1 / 2$, PKCס, Gab2, PI3K, Akt, LAT, ERK1/2, JNK, cPLA 2 , 5-LO and COX-2. Such effects may be derived from the presence of quercetin, which is released from isoquercetin or rutin by naringinase, and provide further insight into the application of MFEN as a therapeutic reagent or a functional food.

\section{Acknowledgements}

This study was financially supported by the Basic Science Research Program through the National Research Foundation of Korea (NRF) funded by the Ministry of Education, Science and Technology (2011-0013606).

\section{References}

1. Yang X, Yang L and Zheng H: Hypolipidemic and antioxidant effects of mulberry (Morus alba $L$.) fruit in hyperlipidaemia rats. Food Chem Toxicol 48: 2374-2379, 2010.

2. Chen PN, Chu SC, Chiou HL, Kuo WH, Chiang CL and Hsieh YS: Mulberry anthocyanins, cyanidin 3-rutinoside and cyanidin 3-glucoside, exhibited an inhibitory effect on the migration and invasion of a human lung cancer cell line. Cancer Lett 235: 248-259, 2006.

3. Kim HG, Ju MS, Shim JS, et al: Mulberry fruit protects dopaminergic neurons in toxin-induced Parkinson's disease models. Br J Nutr 104: 8-16, 2010.

4. Liu LK, Lee HJ, Shih YW, Chyau CC and Wang CJ: Mulberry anthocyanin extracts inhibit LDL oxidation and macrophagederived foam cell formation induced by oxidative LDL. J Food Sci 73: H113-H121, 2008.

5. Pawlowska AM, Oleszek W and Braca A: Quali-quantitative analyses of Flavonoids of Morus nigra L. and Morus alba $L$. (Moraceae) fruits. J Agric Food Chem 56: 3377-3380, 2008.

6. Song W, Wang HJ, Bucheli P, Zhang PF, Wei DZ and Lu YH: Phytochemical profiles of different mulberry (Morus sp.) species from China. J Agric Food Chem 57: 9133-9140, 2009.

7. Ribeiro MH: Naringinases: occurrence, characteristics, and applications. Appl Microbiol Biotechnol 90: 1883-1895, 2011

8. Bram B and Solomons GL: Production of the enzyme naringinase by Aspergillus niger. Appl Microbiol 13: 842-845, 1965.

9. Nomura D: Studies on naringinase produced by Coniothyrium diplodiella. I. The properties of naringinase and the removal of co-existing pectinase from the enzyme preparation. Enzymologia 29: 272-282, 1965.

10. Soria F, Ellenrieder G, Grasselli M, Navarro del Cañizo AA and Cascone O: Fractionation of the naringinase complex from Aspergillus terreus by dye affinity chromatography. Biotechnol Lett 26: 1265-1268, 2004.

11. Magario I, Vielhauer O, Neumann A, Hausmann R and Syldatk C: Kinetic analysis and modeling of the liquid-liquid conversion of emulsified di-rhamnolipids by Naringinase from Penicillium decumbens. Biotechnol Bioeng 102: 9-19, 2009. 
12. Vila-Real H, Alfaia AJ, Bronze MR, Calado AR and Ribeiro MH: Enzymatic synthesis of the flavone glucosides, prunin and isoquercetin, and the aglycones, naringenin and quercetin, with selective alpha-L-rhamnosidase and beta-D-glucosidase activities of naringinase. Enzyme Res 2011: 692618, 2011.

13. Theoharides TC and Kalogeromitros D: The critical role of mast cells in allergy and inflammation. Ann NY Acad Sci 1088: 78-99, 2006.

14. Theoharides TC, Alysandratos KD, Angelidou A, et al: Mast cells and inflammation. Biochim Biophys Acta 1822: 21-33, 2012

15. Gilfillan AM and Tkaczyk C: Integrated signalling pathways for mast-cell activation. Nat Rev Immunol 6: 218-230, 2006.

16. Siraganian RP, McGivney A, Barsumian EL, Crews FT, Hirata F and Axelrod J: Variants of the rat basophilic leukemia cell line for the study of histamine release. Fed Proc 41: 30-34, 1982.

17. Ortega E, Schweitzer-Stenner R and Pecht I: Possible orientational constraints determine secretory signals induced by aggregation of IgE receptors on mast cells. EMBO J 7: 4101-4109, 1988.

18. Funaba M, Ikeda T and Abe M: Degranulation in RBL-2H3 cells: regulation by calmodulin pathway. Cell Biol Int 27: 879-885, 2003.

19. Ikawati Z, Wahyuono S and Maeyama K: Screening of several Indonesian medicinal plants for their inhibitory effect on histamine release from RBL-2H3 cells. J Ethnopharmacol 75 : 249-256, 2001.

20. Ni H, Chen F, Cai H, Xiao A, You Q and Lu Y: Characterization and preparation of Aspergillus niger naringinase for debittering citrus juice. J Food Sci 77: C1-C7, 2012.

21. Lee SY, Lee JY, Kang W, et al: Cytochrome P450-mediated herb-drug interaction potential of Galgeun-tang. Food Chem Toxicol 51: 343-349, 2013.

22. Morita Y and Siraganian RP: Inhibition of IgE-mediated histamine release from rat basophilic leukemia cells and rat mast cells by inhibitors of transmethylation. J Immunol 127: $1339-1344,1981$.

23. Ishiyama M, Tominaga $H$, Shiga $M$, Sasamoto $K$, Ohkura $Y$ and Ueno K: A combined assay of cell viability and in vitro cytotoxicity with a highly water-soluble tetrazolium salt, neutral red and crystal violet. Biol Pharm Bull 19: 1518-1520, 1996.

24. Yoo JM, Park ES, Kim MR and Sok DE: Inhibitory effect of $\mathrm{N}$-Acyl dopamines on IgE-mediated allergic response in RBL-2H3 cells. Lipids 48: 383-393, 2013.
25. Arima $\mathrm{M}$ and Fukuda $\mathrm{T}$ : Prostaglandin $\mathrm{D}_{2}$ and $\mathrm{T}(\mathrm{H})_{2}$ inflammation in the pathogenesis of bronchial asthma. Korean J Intern Med 26: 8-18, 2011.

26. Nettis E, D'Erasmo M, Di Leo E, et al: The employment of leukotriene antagonists in cutaneous diseases belonging to allergological field. Mediators Inflamm 2010: 628171, 2010.

27. Kawakami Y, Kitaura J, Satterthwaite AB, et al: Redundant and opposing functions of two tyrosine kinases, Btk and Lyn, in mast cell activation. J Immunol 165: 1210-1219, 2000.

28. Roth K, Chen WM and Lin TJ: Positive and negative regulatory mechanisms in high-affinity IgE receptor-mediated mast cell activation. Arch Immunol Ther Exp (Warsz) 56: 385-399, 2008.

29. Kim Y, Lee YS, Hahn JH, et al: Hyaluronic acid targets CD44 and inhibits FcepsilonRI signaling involving PKCdelta, Rac1, ROS, and MAPK to exert anti-allergic effect. Mol Immunol 45: 2537-2547, 2008

30. Morimoto Y, Yasuhara T, Sugimoto A, et al: Anti-allergic substances contained in the pollen of Cryptomeria japonica possess diverse effects on the degranulation of RBL-2H3 cells. J Pharmacol Sci 92: 291-295, 2003.

31. Han SJ, Ryu SN, Trinh HT, et al: Metabolism of cyanidin3-O-beta-D-glucoside isolated from black colored rice and its antiscratching behavioral effect in mice. J Food Sci 74: $\mathrm{H} 253-\mathrm{H} 258,2009$.

32. Gomez G, Gonzalez-Espinosa C, Odom S, et al: Impaired FcepsilonRI-dependent gene expression and defective eicosanoid and cytokine production as a consequence of Fyn deficiency in mast cells. J Immunol 175: 7602-7610, 2005.

33. Metcalfe DD: Mast cells and mastocytosis. Blood 112: 946-956, 2008.

34. Ford-Hutchinson AW, Bray MA, Doig MV, Shipley ME and Smith MJ: Leukotriene B, a potent chemokinetic and aggregating substance released from polymorphonuclear leukocytes. Nature 286: 264-265, 1980.

35. Tager AM and Luster AD: BLT1 and BLT2: the leukotriene B(4) receptors. Prostaglandins Leukot Essent Fatty Acids 69: 123-134, 2003.

36. Gordon JR and Galli SJ: Mast cells as a source of both preformed and immunologically inducible TNF-alpha/cachectin. Nature 346: 274-276, 1990 